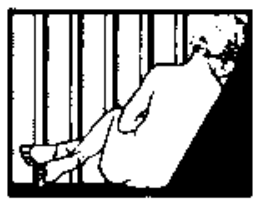

\title{
Movimento nacional de meninos e meninas de rua
}

Este Movimento começou a existir em 1982 e se constituiu como uma entidade civil independente em 1985 , tendo atualmente 5 sedes re. gionais espalhadas pelas principais Capitais do País. Este Movimento não presta atendimento direto aos menores, mas procura mobilizar os próprios menores, os técnicos, os educadores de rua, os diretores, os funcionários de instituiçōes, enfim todos os que estào envolvidos com este segmento da população brasileira. Dentro desta perspectiva de mobilização, o Movimento não está atrelado à Igreja e nem ao Estado, tendo garantida sua independência financeira por subsídios de 3 entidades internacionais (entre elas, a UNICEF).

Reinaldo Bulgarelli, coordenador da Regiāo Sudeste, fez as seguintes declaraçōes: "Em 1987, privilegiamos o fortalecimento do Movimento através da organização das co. missões locais que atuam nas diversas sedes regionais. Em 88, vamos dar mais prioridade à formação e atuação dos educadores no trabalho de rua. Estamos conseguindo legitimar essa prática alternativa que até agora acontecia nos porōes das instituiçōes pertencentes ao Estado ou às entidades civis. Essa é uma tentativa significativa de superar a política do bem-estar do menor criada em 1964, mas que de 'bem-estar do menor' nào tem nada.

Ao fortalecer as práticas alternativas que visam à mudança do trabatho institucional com os menores, cavamos brechas para justamente influenciar uma nova postura de trabalho. As vezes, é uma posição de confronto que se torna inevitável nesta nossa proposta. Por exemplo, pode tornar-se dificil dialogar com a FEBEM e esta dificuldade não é a de falar com o presidente da entidade, mas porque a prática da instituição em si mesma já ć uma violência, com contenção e repressão, e nada mais.

O Movimento não pretende somente formar ou rever as práticas de atuação, mas também reunir os diferentes técnicos, educadores, diretores, funcionários etc., para discutir em conjunto suas práticas e se organizarem para interferir na política nacional. Para tanto promovemos, nas sedes regionais, vários encontros e eventos, nos quais a participação não se dá em nome da instituiçāo e nem de compromissos político-partidários, mas em nome pessoal de cada participante. Isso dá uma riqueza maior ao Movimento se todos estão comprometidos com os menores numa luta em conjunto. Também sảo promovidos encontros nacionais em que um dos temas discutidos é a nossa identidade enquanto Movimento. Esta torna-se mais clara na medida em que vamos caminhando. Ainda é muito difícil ter essa identidade a nivel nacional, mas esses encontros são importantes para ir dando feição ao Movimento.

Outra dimensão de participação no Movimento é a das crianças. Em 86, fizemos um encontro nacional de meninos de rua, em Brasília, que teve repercussảo até internacional, para demonstrar como eles são capazes de estar fazendo suas reivindicaçōes. De lá para cá, surgiram várias comissōes de crianças. No Estado de Sảo Paulo tem uma dessas comissōes que se reúne para discutir a situação dos joveńs, que vivem uma condição de marginalização quase total, e também para propor opçōes deles a nivel local. Assim, eles começam a se organizar nas diversas regiōes do País e nós vamos estar colaborando com eles. Inclusive, estamos atentos para que, atra- vés do diálogo e da troca de idéias, a nossa colaboração se efetive de forma que nảo seja imposto para eles um modelo de organizaçảo e de ação.

Em termos mais amplos, o objetivo do Movimento é o de não ficar restrito ao atendimento dos menores, mas procurar conquistar um espaço de luta maior, organizando-se como um movimento popular e atuando junto com outros movimentos populares. É uma ligaçāo que dificilmente as pessoas fazem, porque a questảo dos menores é vista como isolada de outras questões sociais. Os próprios Sindicatos não vêem os menores como filhos de trabalhadores que já estào bem afastados da familia. Para reverter esta constataçào, procuramos fazer com que os grupos se articulem e cada ação direta com os menores não fique isolada, mas possa ser multiplicada e tenha uma dimensão mais ampla da realidade da criança que, no fundo, é uma postura diferente em relaçāo à pobreza e à maneita de se lidar com ela."

O Movimento é aberto à participação da população e nảo possui qualquer espécie de filiaçāo dos seus participantes. Sua sede nacional fica no seguinte endereço: SDN - CNB - $3^{\circ}$ andar - sala L. 403 , CEP 70.070, Brasília, DF.

As sedes regionais possuem os endereços:

Sudeste - Rua André Cavalcanti, 23, CEP20.231, R.de Janeiro. RJ. (Em São Paulo, Praça da Sé, 184, conj. 702, CEP 01001,SP).

Nordeste - Rua Floriano Peixoto, 85, CEP 54.110, Recife, PE.

Norte - Av. Dom Romualdo de Seixas, 918, CEP 66.030, Belém, PA.

Sul - R. Esteves Júnior, 105, CEP 88.010, Florianópolis, SC. 